\title{
FACTORS INFLUENCING THE INTENTION OF USING Tax Consulting Services of Companies in Ho Chi Minh City: A Structural Equation Model
}

\author{
Thao NGUYEN-TRANG ${ }^{1,2, *}$, Long VU-HOANG ${ }^{2}$, Trieu NGUYEN-THI ${ }^{3}$, \\ Ha CHE-NGOC ${ }^{2}$
}

\begin{abstract}
${ }^{1}$ Division of Computational Mathemactics and Engineering, Institite for Computational Science, Ton Duc Thang University, Ho Chi Minh City, Vietnam

${ }^{2}$ Faculty of Mathematics and Statistics, Ton Duc Thang University, Ho Chi Minh City, Vietnam ${ }^{3}$ Faculty of Accounting, Ton Duc Thang University, Ho Chi Minh City, Vietnam
\end{abstract}

$$
\text { *nguyentrangthao@tdt.edu.vn }
$$

(Received: 09-August-2017; accepted: 03-October-2017; published: 30-November-2017)

DOI: http://dx.doi.org/10.25073/jaec.201712.62

\begin{abstract}
Tax consulting service is one of various professional consulting services and is interested to study by many researchers. Nevertheless, this issue has not been interested to research in Vietnam. This paper performs Confirmatory Factor Analysis (CFA) and Structural Equation Modeling (SEM) to identify the factors influencing the intention of using tax consulting services of companies in Ho Chi Minh city, Vietnam. Specifically, this paper finds that the intention depends on the "attitude toward the behavior" and "replacement". In addition, through Chi-square test, it can be proven that the intention also depends on the type of companies and whether they have ever used tax consulting service or not. Based on the obtained results, the discussion and recommendation are proposed.
\end{abstract}

\section{Keywords}

Factor, structural equation modeling, tax consulting service.

\section{Introduction}

Tax consulting service is one of various professional consulting services, so it is interested to study by many researchers [1, [2] and [3]. The tax consultants with their profound knowledge and understanding of tax law, can provide the most professional advices and solutions for their clients. They provide orientation and correct interpretation of the tax law so that the taxpayers can use most efficiently and minimize the amount of tax payable while ensuring the legal compliance. Consultants can examine all aspects of tax to ensure providing the best tax strategy for the financial activities of their clients in the future as well as represent their clients to implement tax obligations to the state. According to the report from the Tax Consulting Association, there are currently 79 tax agents in Ho Chi Minh city (updated on 16/3/2015) and many companies providing tax consulting services such as Pricewaterhouse Coopers (PWC), Deloitte (DTT), and Ernst \& Young (E\&Y). A concern is that there are a lot of consulting companies and the service usefulness is easy to recognize; however, the number of companies used this service is only about 300 companies which is a greatly small figure compared to the num- 
ber of existing companies in Ho Chi Minh City (HCMC). Hence, a necessary work is to study the factors affecting the intention to use tax consulting services in companies in Ho Chi Minh City, thereby clarify the situation and provide solutions for tax agents and tax consulting service providers so that they can become a bridge between the tax authorities and taxpayers, can support and facilitate taxpayers to comply with the tax law, can reduce the costs of time and resources for both the tax authorities and taxpayers to comply with law and can contribute to improving the efficiency of management. Nevertheless, the problem metioned above has not been interested to study in Vietnam yet. The research of Trieu et al. [4 that applied the adjusted Theory of Planned Behavior model $[5]$ to analyze, predict intention of using tax consulting services of companies in HCMC, Vietnam was also the unique research in literatures. The reason why [4] applied Theory of Planned Behavior (TPB) is it has an additional important factor, perceived behavioral control, which also affect people's intention. Perceived behavioral control reflects the ease or difficulty in performing behaviors and whether such behavior performance is controlled or limited or not. It represents the resources necessary for a person to perform any kinds of job. They think the more resources and opportunities, the fewer obstacles and higher perception control of behavior are. This control factor may be derived from within an individual (motivation and capacity) or outside an individual (time, opportunity, economic conditions, etc.). Therefore, TPB model is considered more reasonable than other existing ones like Theory of Reasoned Action [6], Technology acceptance model [7] in predicting and explaining the behavior of the consumer in the same research conditions and contents $([8,[9,[10$, [11] and [12]). Furthermore, in [4, the author used three factors of the TPB model, which include attitude toward the behavior, subjective norm, and perceived behavioral control, in combination with replacement, a newly added factor. The new factor is added due to the fact that most Vietnamese companies hire their own accountants. Accountants in companies are responsible for declaring and making tax settlements, tax plans; as a result, it can strongly affect the intention of using tax consulting ser- vices. The results in 4 presented that companies in HCMC are most interested in the usefulness of the product rather than replacement or other external impacts. However, in that study, there are a few issues need to be clarified and improved such as:

1. The relationships between intention of using tax consulting services and moderator groups were not examined although those moderator groups may had significant effects on the intention of using tax consulting service.

2. The lack of stability in Cronbach's alpha and EFA testing: the EFA can help explore and identify the number of latent constructs and the underlying factor structure, without any prior knowledge. It is really useful when the prolem is new and when we add some new variables 13. However, in case of the current research, when the knowledge of problem was proposed in 4, the major objective is not to explore the new model but to test the hypothesis about the relationships between the existing variables and underlying latent constructs, which is other models like CFA or SEM can do well [14.

3. The drawback of sample size: The sample size 112 used in [4 is enough to conclude that the whole data follows normal distribution; however, when we divide the data into moderator groups and perform further analysis, it is not guaranteed that each group, with a smaller sample size, follows the normal distribution. In addition, a sample of size $n=112$ is not a good representative sample of the population with a large number of companies in HCMC (according to a report of General Statistics Office of Vietnam, there are about 200000 companies in Ho Chi Minh city).

Hence, this study is proposed to overcome the limitations of [4. Specifically, (1)We collect more informations about companies investigated by 4 . Because the variables in moderator groups including type and field of company are often nominal scale variables, we apply the chi-square test instead 
of other techniques (correlation coefficient, regression, EFA, CFA, etc) to discover the relationships between moderator groups and the intention of using tax consulting service. (2)- We perform several further experiments such as Confirmatory Factors Analysis (CFA), Structural Equation Modeling (SEM) to identify the best model. In addition to test the hypothesis about the relationships between the existing variables and underlying latent constructs, SEM is considered as a succession of structural equations, which is similar to running several regression equations. (3)- The drawback of small sample size is overcomed by bootstrap method. The bootstrap [15] is the resampling with replacement for estimating the sampling distribution of parameter including model coefficients and their respective standard errors. In the fields of EFA and CFA, Chatterjee [16] proposed the use of bootstrap standard errors for the first time. The use bootstrap for factor analysis was then studied by a large number of researchers. Lambert et al. 17] studied the bootstrap confidence intervals for factor loadings and used them to interprete factors. Bollen and Stine [18 and [19] applied the bootstrap methods to structural equation models where confirmatory factor analysis is a special case. A full simulation study of the bootstrap methods in factor analysis was conducted by Ichikawa and Konishi [20. They proved that bootstrap-estimated standard errors are less biased than the traditional maximum likelihood under nonnormality. In general, it can be seen that the bootstrap is really a potential alternative strategy for obtaining robust statistics in SEM [21. According to the above references, this paper utilizes bootstrap method, especially the Bollen-Stine bootstrapping procedure, to provide more reliable results. The result in this study is different from that of [4], especially, attitude toward the behavior (A) and attractiveness of replacement (D) are the two most important factors influencing intention of using tax consulting service $(\mathrm{F})$.

The remainder of this paper is organized as follows. The research methodology in Sec. [ $2 . \quad$ presents an overview of data and related analysis techniques. Based on the detailed results shown in Sec. 3.
Sec. 4. discusses and proposes some recommendations. The final section is the conclusion.

\section{Research Methodlogy}

Data: In addition to the secondary data taken by [4, we collect more information of 112 companies, such as the type, size, and field of companies to discover the relationships between them and the intention. The sample structure is described through Tab. 1

Tab. 1: The sample structure.

\begin{tabular}{|l|c|c|}
\hline Type of company & Frequency & Percent \\
\hline Joint stock & 14 & 12.500 \\
\hline Limited liability & 73 & 65.179 \\
\hline Private enterprise & 21 & 18.750 \\
\hline Other & 4 & 3.571 \\
\hline Total & 112 & 100 \\
\hline Fied of company & Frequency & Percent \\
\hline Producing company & 18 & 16.071 \\
\hline Trading company & 44 & 39.286 \\
\hline Trading and producing company & 22 & 19.643 \\
\hline Service company & 19 & 16.964 \\
\hline Other & 9 & 0.89 \\
\hline Total & 112 & 100 \\
\hline Size of company & Frequency & Percent \\
\hline Small size & 88 & 78.571 \\
\hline Medium size & 21 & 18.750 \\
\hline Large size & 3 & 2.679 \\
\hline Total & 112 & 100 \\
\hline
\end{tabular}

Data analysis: Based on the obtained results in [4, this article conducts Confirmatory Factors Analysis Test (CFA) and establishes Structural Equation Modeling (SEM) to determine the best model. Furthermore, the bootstrap method is applied to overcome the limitation of small sample size and the Chi-square test is performed to consider the relationships between intention and moderator groups.

\section{The Result of this Study}

After performing the Cronbach's alpha and Exploratory Factor Analysis EFA, 4] proposed a model consisting of five independent factors (see Tab. 22. The independent factors include: Atti- 
tude toward the behavior (A) measured by six observed variables: A1: Convenient, A3: Cost saving, A4: Avoiding errors for the declaration and payment of tax, A5: Timely and rapid updates with new provisions of law, A6: Optimization of methods of administrative procedures affects decisions, B3: Right updates affect decisions to use; Subjective Norms 1 (B) measured by four observed variables: A6: Optimization of methods of administrative procedures affects decisions, B1: Recommended by colleagues/friends, B5: Incentive policy of state affects decisions, C4: I intend to use tax consulting services in the near future; Perceived behavioral control (C) mesured by three observed variables: C1: I decided the use of services, C2: I can study and make decisions easily, C3: I select companies with moreprestige in this field; Attractiveness of replacement (D) measured by three observed variables: D1: Accountants will better manage information, D2: Accountants will give information faster and more punctual when I need, D3: Hiring consulting services is more expensive than hiring accountants; Subjective Norms 2 measured by two observed variables: B2: Recommended by partners, B4: Advertising affects the choice. The dependent variable is Intention of using tax consulting services which measured by three items: F1: Companies intend to use tax consulting services, F2: Companies intend to use tax consulting services regularly, F3: Companies intend to advise friends/partners use tax consulting services. Through the varibles metioned above, the Confirmatory Factor Analysis (CFA), Structural Equation Analysis (SEM) and Boostrap method are then performed in this article. The detailed results are presented by following subsections.

\subsection{Confirmatory Factor Analysis (CFA)}

The result of Confirmatory Factor Analysis (CFA) of Trieu's model is shown in Fig. 1

According to [22], 23], [24] and [25], GFI, TLI, and CFI values below 0.90 indicates that the fit of the model to the data is less than satisfactory. It can be observed from Fig. 1 that the goodness of fit index of the unadjusted model is
Tab. 2: Last obtained EFA result from 4 .

\begin{tabular}{|c|c|c|c|c|c|}
\hline & \multicolumn{5}{|c|}{ Component } \\
\hline & $\mathbf{1}$ & $\mathbf{2}$ & $\mathbf{3}$ & $\mathbf{4}$ & $\mathbf{5}$ \\
\hline A4 & 0.716 & & & & \\
\hline A5 & 0.699 & & & & \\
\hline A1 & 0.677 & & & & \\
\hline B3 & 0.564 & & & & \\
\hline A6 & 0.560 & 0.518 & & & \\
\hline A3 & 0.537 & & & & \\
\hline B5 & & 0.856 & & & \\
\hline B1 & & 0.715 & & & \\
\hline C4 & & 0.510 & & & \\
\hline C3 & & & 0.818 & & \\
\hline C1 & & & 0.702 & & \\
\hline C2 & & & 0.577 & & \\
\hline B2 & & & & 0.851 & \\
\hline B4 & & & & 0.801 & \\
\hline D1 & & & & & 0.832 \\
\hline D3 & & & & & 0.738 \\
\hline D2 & & & & & 0.684 \\
\hline
\end{tabular}

not as satisfying as expected (GFI $=0.821<$ 0.9$, TLI $=0.835<0.9$, CFI $=0.865<0.9)$. Therefore, an adjusted model needs to be established. The adjusted model is illustrated by Fig. 2. Table. 1 presents the results of both unadjusted and adjusted model for comparison purpose.

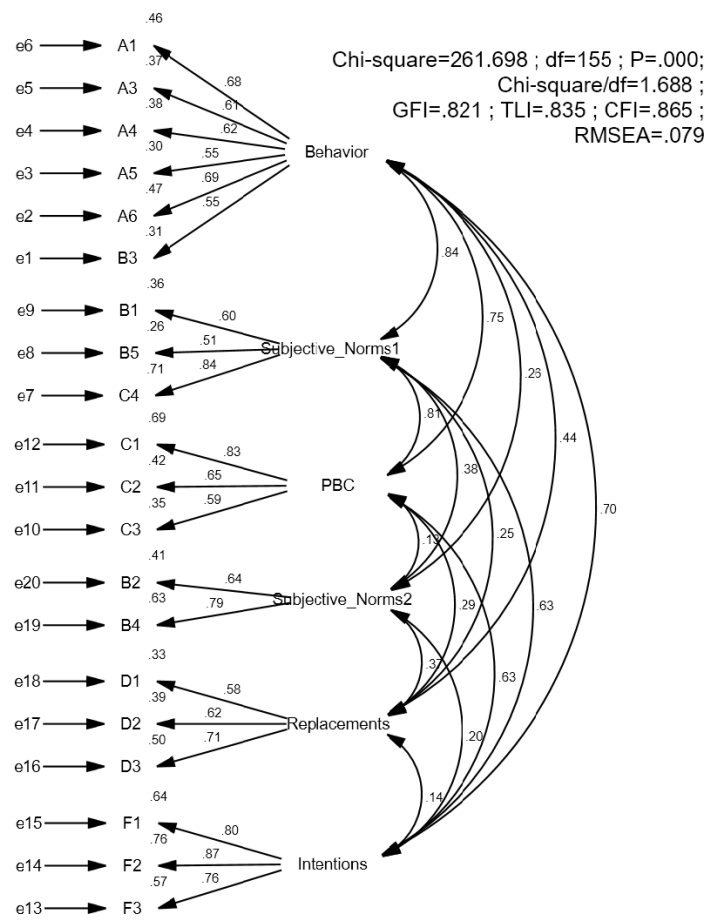

Fig. 1: Result of CFA of unadjusted model. 


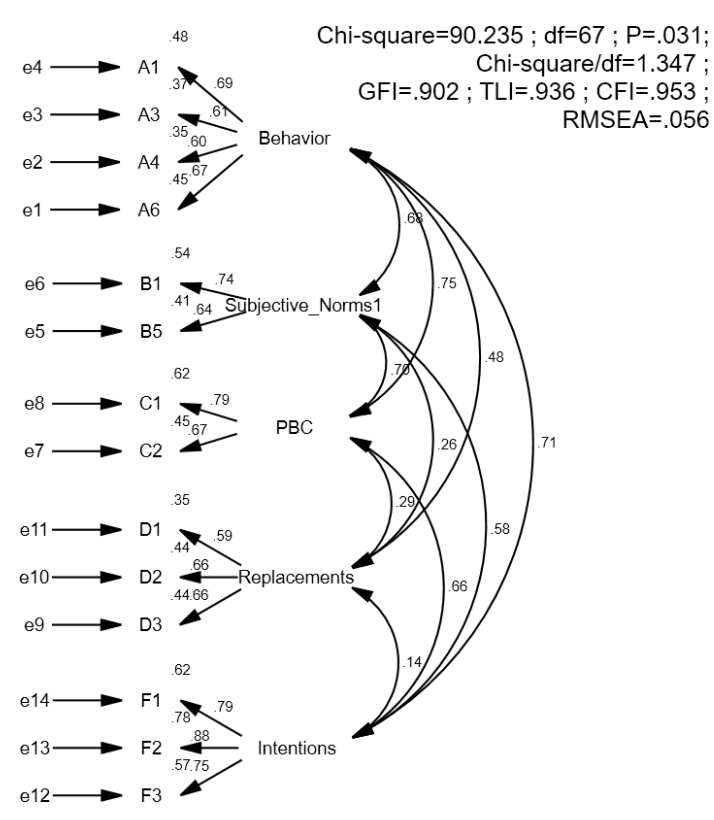

Fig. 2: CFA result of adjusted model.

Tab. 3: The results of unadjusted and adjusted model.

\begin{tabular}{|c|c|c|}
\hline Index & Unadjusted model & Adjusted model \\
\hline$\chi^{2}$ & 261.698 & 90.235 \\
\hline $\mathrm{df}$ & 155 & 67 \\
\hline$\chi^{2} / \mathrm{df}$ & 1.688 & 1.347 \\
\hline $\mathrm{p}$ & 0.000 & 0.031 \\
\hline $\mathrm{GFI}$ & 0.821 & 0.92 \\
\hline $\mathrm{TLI}$ & 0.835 & 0.936 \\
\hline $\mathrm{CFI}$ & 0.865 & 0.953 \\
\hline RMSEA & 0.079 & 0.056 \\
\hline
\end{tabular}

It can be seen from Fig. 2 and Tab. 3 that all of the goodness of fit indexes are now greater than 0.9 and indicate a good model (GFI $=0.92$, TLI $=0.936$, $\mathrm{CFI}=0.953)$. Moreover, an adequate model fit is indicated when the Root Mean Square Error of Approximation value (RMSEA) is smaller than $0.06[26]$ and the ratio of chi-square to degrees of freedom is 1.347 [27, and 28. During the process of evaluating several iterations of CFA, six problematic items and one factor are deleted from the model (item A5: Timely and rapid updates with new provisions of law, B3: Right updates affect decisions to use in Attitude toward the behavior (A), item $\mathrm{C} 4$ : I intend to use tax consulting services in the near future in Subjective Norms 1 (B), item C3: I select companies with moreprestige in this field in Perceived be-
Tab. 4: Results of Regression Weights.

\begin{tabular}{|c|c|c|c|c|c|c|}
\hline & & & Estim. & S.E. & C.R. & $\mathbf{P}$ \\
\hline A3 & $\leftarrow$ & $\begin{array}{l}\text { Attitude } \\
\text { toward the } \\
\text { behavior }\end{array}$ & 1.000 & & & \\
\hline A 6 & $\leftarrow$ & $\begin{array}{l}\text { Attitude } \\
\text { toward the } \\
\text { behavior }\end{array}$ & 1.181 & 0.219 & 5.385 & $* * *$ \\
\hline A1 & $\leftarrow$ & $\begin{array}{c}\text { Attitude } \\
\text { toward the } \\
\text { behavior }\end{array}$ & 1.214 & 0.221 & 5.504 & $* * *$ \\
\hline A4 & $\leftarrow$ & $\begin{array}{c}\text { Attitude } \\
\text { toward the } \\
\text { behavior }\end{array}$ & 0.968 & 0.195 & 4.965 & $* * *$ \\
\hline B1 & $\leftarrow$ & $\begin{array}{l}\text { Subjective } \\
\text { Norm } 1\end{array}$ & 1.262 & 0.263 & 4.803 & $* * *$ \\
\hline B5 & $\leftarrow$ & $\begin{array}{l}\text { Subjective } \\
\text { Norm } 1\end{array}$ & 1.000 & & & \\
\hline $\mathrm{C} 2$ & $\leftarrow$ & $\begin{array}{l}\text { Perceived } \\
\text { behavioral } \\
\text { control }\end{array}$ & 0.841 & 0.144 & 5.827 & $* * *$ \\
\hline $\mathrm{C} 1$ & $\leftarrow$ & $\begin{array}{l}\text { Perceived } \\
\text { behavioral } \\
\text { control }\end{array}$ & 1.000 & & & \\
\hline D3 & $\leftarrow$ & $\begin{array}{l}\text { Attracti. of } \\
\text { replacement }\end{array}$ & 1.000 & & & \\
\hline D2 & $\leftarrow$ & $\begin{array}{l}\text { Attracti. of } \\
\text { replacement }\end{array}$ & 0.819 & 0.189 & 4.333 & $* * *$ \\
\hline D1 & $\leftarrow$ & $\begin{array}{l}\text { Attracti. of } \\
\text { replacement }\end{array}$ & 0.720 & 0.171 & 4.212 & $* * *$ \\
\hline F3 & $\leftarrow$ & $\begin{array}{l}\text { Intention of } \\
\text { using tax } \\
\text { consulting }\end{array}$ & 1.000 & & & \\
\hline $\mathrm{F} 2$ & $\leftarrow$ & $\begin{array}{c}\text { Intention of } \\
\text { using tax } \\
\text { consulting }\end{array}$ & 1.276 & 0.145 & 8.793 & $* * *$ \\
\hline F1 & $\leftarrow$ & $\begin{array}{c}\text { Intention of } \\
\text { using tax } \\
\text { consulting }\end{array}$ & 0.927 & 0.115 & 8.096 & $* * *$ \\
\hline
\end{tabular}

havioral control (C) and Subjective Norms 2). As a result, the current adjusted model contains five factors: Attitude toward the behavior (A), Subjective Norms 1 (B), Perceived behavioral control (C), Attractiveness of replacement (D), Intention of using tax consulting services $(\mathrm{F})$. Table 4 and Tab. 5 present that their standardized Regression Weights are greater than 0.5 and $p$-value are smaller than 0.05 ; hence, observed variables demonstrate convergent validity [29]. Furthermore, Tab. 6 present that the pairwise correlation coefficients between five factors are smaller than 1. Therefore, five factors achieve discriminant validity. Due to all features mentioned above, the model is supposed as 
Tab. 5: Results of Standardized Regression Weights.

\begin{tabular}{|c|c|c|c|}
\hline & & & Estimate \\
\hline A3 & $\leftarrow$ & $\begin{array}{l}\text { Attitude toward } \\
\text { the behavior }\end{array}$ & 0.609 \\
\hline A6 & $\leftarrow$ & $\begin{array}{l}\text { Attitude toward } \\
\text { the behavior }\end{array}$ & 0.667 \\
\hline $\mathrm{A} 1$ & $\leftarrow$ & $\begin{array}{l}\text { Attitude toward } \\
\text { the behavior }\end{array}$ & 0.690 \\
\hline A4 & $\leftarrow$ & $\begin{array}{l}\text { Attitude toward } \\
\text { the behavior }\end{array}$ & 0.596 \\
\hline $\mathrm{B} 1$ & $\leftarrow$ & Subjective Norm 1 & 0.738 \\
\hline B5 & $\leftarrow$ & Subjective Norm 1 & 0.637 \\
\hline $\mathrm{C} 2$ & $\leftarrow$ & $\begin{array}{c}\text { Perceived } \\
\text { behavioral control }\end{array}$ & 0.670 \\
\hline $\mathrm{C} 1$ & $\leftarrow$ & $\begin{array}{c}\text { Perceived } \\
\text { behavioral control }\end{array}$ & 0.785 \\
\hline D3 & $\leftarrow$ & $\begin{array}{l}\text { Attractiveness } \\
\text { of replacement }\end{array}$ & 0.663 \\
\hline D2 & $\leftarrow$ & $\begin{array}{l}\text { Attractiveness } \\
\text { of replacement }\end{array}$ & 0.663 \\
\hline D1 & $\leftarrow$ & $\begin{array}{l}\text { Attractiveness } \\
\text { of replacement }\end{array}$ & 0.588 \\
\hline F3 & $\leftarrow$ & $\begin{array}{l}\text { Intention of using } \\
\text { tax consulting }\end{array}$ & 0.753 \\
\hline $\mathrm{F} 2$ & $\leftarrow$ & $\begin{array}{l}\text { Intention of using } \\
\text { tax consulting }\end{array}$ & 0.883 \\
\hline F1 & $\leftarrow$ & $\begin{array}{l}\text { Intention of using } \\
\text { tax consulting }\end{array}$ & 0.786 \\
\hline
\end{tabular}

achieved reliability and can be further analysed by structural equation modeling.

\subsection{Structural Equation Modeling (SEM)}

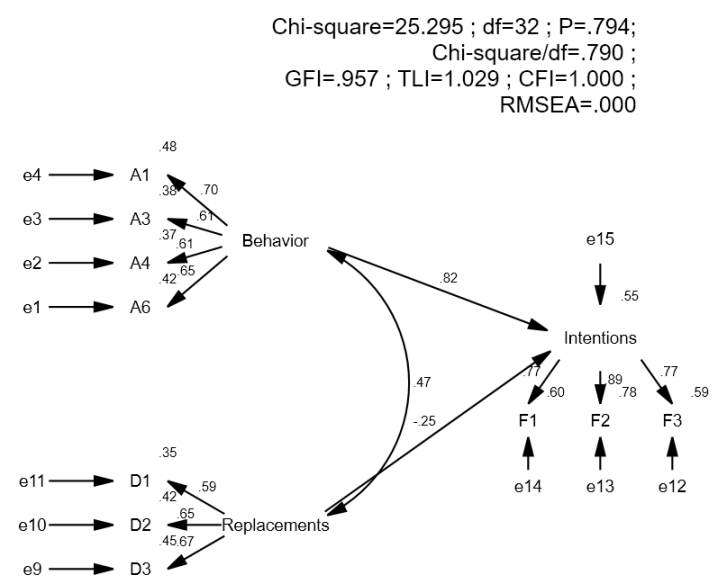

Fig. 3: Result of the first SEM.

Although Fig. 3 has presented the reliability of the model, the regression estimation argued In-
Tab. 6: Results of discriminant validity tests.

\begin{tabular}{|c|c|c|c|c|}
\hline & & & $r$ & $p$-value \\
\hline $\begin{array}{l}\text { Attitude } \\
\text { toward the } \\
\text { behavior }\end{array}$ & $\leftarrow \rightarrow$ & $\begin{array}{l}\text { Subjective } \\
\text { Norm } 1\end{array}$ & 0.685 & 0.000 \\
\hline $\begin{array}{l}\text { Subjective } \\
\text { Norm } 1\end{array}$ & $\leftarrow \rightarrow$ & $\begin{array}{c}\text { Perceived } \\
\text { behavioral } \\
\text { control }\end{array}$ & 0.703 & 0.000 \\
\hline $\begin{array}{c}\text { Attractiveness } \\
\text { of replacement } \\
\text { behavior }\end{array}$ & $\leftarrow \rightarrow$ & $\begin{array}{c}\text { Intention of } \\
\text { using tax } \\
\text { consulting }\end{array}$ & 0.142 & 0.000 \\
\hline $\begin{array}{c}\text { Attitude } \\
\text { toward the } \\
\text { behavior }\end{array}$ & $\leftarrow \rightarrow$ & $\begin{array}{c}\text { Perceived } \\
\text { behavioral } \\
\text { control } \\
\end{array}$ & 0.749 & 0.000 \\
\hline $\begin{array}{l}\text { Attitude } \\
\text { toward the } \\
\text { behavior }\end{array}$ & $\leftarrow \rightarrow$ & $\begin{array}{l}\text { Attractiveness } \\
\text { of replacement }\end{array}$ & 0.475 & 0.000 \\
\hline $\begin{array}{l}\text { Attitude } \\
\text { toward the } \\
\text { behavior }\end{array}$ & $\leftarrow \rightarrow$ & $\begin{array}{c}\text { Intention of } \\
\text { using tax } \\
\text { consulting }\end{array}$ & 0.580 & 0.000 \\
\hline $\begin{array}{l}\text { Subjective } \\
\text { Norm } 1\end{array}$ & $\leftarrow \rightarrow$ & $\begin{array}{l}\text { Attractiveness } \\
\text { of replacement }\end{array}$ & 0.259 & 0.000 \\
\hline $\begin{array}{l}\text { Subjective } \\
\text { Norm } 1\end{array}$ & $\leftarrow \rightarrow$ & $\begin{array}{c}\text { Intention of } \\
\text { using tax } \\
\text { consulting }\end{array}$ & 0.580 & 0.000 \\
\hline $\begin{array}{c}\text { Perceived } \\
\text { behavioral } \\
\text { control }\end{array}$ & $\leftarrow \rightarrow$ & $\begin{array}{l}\text { Attractiveness } \\
\text { of replacement }\end{array}$ & 0.292 & 0.000 \\
\hline $\begin{array}{c}\text { Perceived } \\
\text { behavioral } \\
\text { control } \\
\end{array}$ & $\leftarrow \rightarrow$ & $\begin{array}{c}\text { Intention of } \\
\text { using tax } \\
\text { consulting }\end{array}$ & 0.662 & 0.000 \\
\hline
\end{tabular}

tention of using tax consulting (F) does not depend on Subjective Norms 1 (B) and Perceived behavioral control $(\mathrm{C})$. Therefore, these factors are deleted from the model and the second model is performed (Fig. 4).

It can be seen that the index to evaluate the overall fit of the data to model is higher, especially TLI and CFI values are greater or equal to 1 (Fig. 4 Hence, it is possible to conclude that the model is perfect [27] and [28].

The new model contains three factors with ten items, where the influence of Attitude toward the behavior (A) on Intention of using tax consulting services $(\mathrm{F})$ is positive $(0.82)$. That means if the companies recognize the usefulness of tax consulting services, especially the convenience-the most important item in Attitude toward the behavior (A) (0.69), they will intend to use them. In contrast, attractiveness of replacement (D) is inversely proportional to the Intention of using tax consulting services $(\mathrm{F})$ $(-0.025)$. It is believed that if the companies are 
attracted by replacement, their intention of using tax consulting service will be reduced. The major reason is the cost of service. Figure 4 presents that "the Hiring consulting services is more expensive than hiring accountants" is the most important item in variable (D) (variable D2 in Fig. 4 has the biggest regression weight in this model). Clearly, the pricing issues is the major disadvantage of tax consulting services nowaday. Additionally, for small and medium-sized enterprises in Vietnam, the number of transactions is not too large; therefore, those transactions can be handled well by the company's own accountant. Consequently, using tax consulting services is not necessary for these businesses.

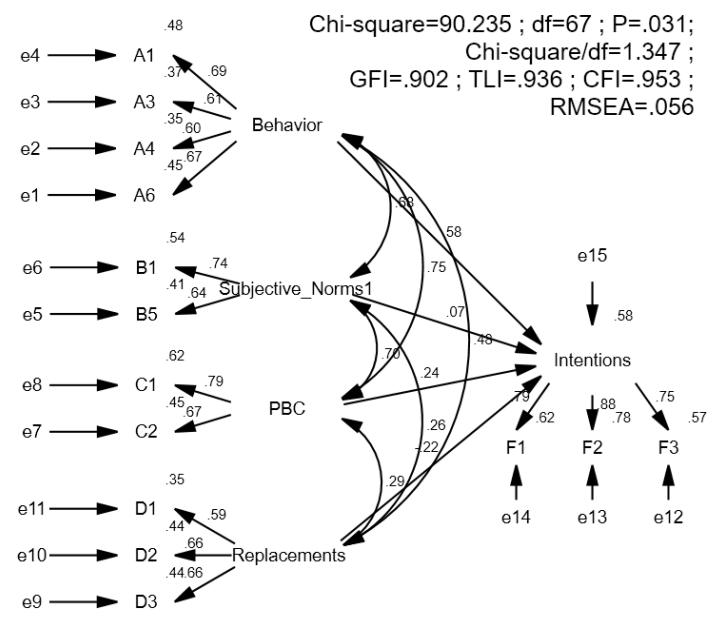

Fig. 4: Result of the second SEM.

Through these results, tax consulting service companies have to deal with their limited usefulness and high cost service to raise the intention of companies in Vietnam, especially in Ho Chi Minh city.

In this study, the intention of using tax consulting services (F) depends on the Attitude toward the behavior (A) and the Attractiveness of replacement (D) whereas it depends on the Attitude toward the behavior (A), Subjective Norms 1 (B) and Perceived behavioral control (C) in [4]. It can be clearly seen that the Structural Equation Modeling test is more reliable than Cronbach's alpha and EFA in [4]. In addition, to overcome small sample size problem in 4], the stability and reliability of the proposed model are tested by Bootstrap method in the next subsection.

\subsection{Bootstrap Method}

To overcome the small sample size limitation in 4 $(\mathrm{N}=112)$, bootstrap method that is based on random sampling with replacement is performed to create a larger number of samples $(\mathrm{N}=800)$. Let the null hypothesis be that there is not difference of standardized regression weight between the estimated model and bootstrap model. Because the sample size is greater than 30 then this model can be performed as approximate z-test. Given significance level 0.05 in a two-tailed test, the z-test has a single critical value at 1.96. Hence, we can reject the hypothesis if the $\mathrm{z}$-computed value is greater or beyond 1.96 (see [30] for more details). It can be seen from Tab. 7 that the magnitude of the bias is less than 1.96. That means estimated model in Fig. 4 is reliable.

Tab. 7: Result of bootstrap estimation.

\begin{tabular}{|c|c|c|c|c|c|}
\hline \multicolumn{3}{|c|}{ Relationship } & SE & SE-SE & Mean \\
\hline Intention & $\leftarrow$ & Behavior & 0.124 & 0.003 & 0.832 \\
\hline Intention & $\leftarrow$ & Replac. & 0.151 & 0.004 & -0.253 \\
\hline \multicolumn{3}{|c|}{ Relationship } & Bias & SE-Bias & CR \\
\hline Intention & $\leftarrow$ & Behavior & 0.007 & 0.004 & 0.571 \\
\hline Intention & $\leftarrow$ & Replac. & -0.007 & 0.005 & -0.714 \\
\hline
\end{tabular}

\subsection{The Relationships Between Intention and Moderated Factors}

Another limitation of [4] is that it did not consider the relationships between the intention of using tax consulting service and moderator groups such as field, type and size of companies. Because those moderator groups may have significant effects on the intention of using tax consulting service, this subsection clarifies those hypotheses through chi-squared test. Let a null hypothesis be that "the intention is independent on $X^{\prime \prime}$, with $X$ is the current considered moderator group. With the significance level 0.05, Tab. 8 demonstrates that the intention do 
not depend on the field and size of companies but depend on their type and whether they have ever used tax consulting service or not.

Tab. 8: Results of Chi-square test.

\begin{tabular}{|l|c|c|}
\hline \multicolumn{1}{|c|}{ Hypothesis } & p-value & \multicolumn{1}{c|}{ Conclusion } \\
\hline $\begin{array}{l}\text { Intention of using tax } \\
\text { consulting service } \\
\text { areindependent on } \\
\text { kind of company. }\end{array}$ & 0.022 & $\begin{array}{l}\text { Reject,the } \\
\text { null hypothesis. }\end{array}$ \\
\hline $\begin{array}{l}\text { Intention of using } \\
\text { tax consulting service } \\
\text { are independent on } \\
\text { fied of company. }\end{array}$ & 0.499 & $\begin{array}{l}\text { Cannot reject the } \\
\text { null hypothesis. }\end{array}$ \\
\hline $\begin{array}{l}\text { Intention of using } \\
\text { tax consulting service } \\
\text { are independent on } \\
\text { size of company. }\end{array}$ & 0.805 & $\begin{array}{l}\text { Cannot reject the } \\
\text { null hypothesis. }\end{array}$ \\
\hline $\begin{array}{l}\text { Intention of using } \\
\text { tax consulting service } \\
\text { are independent on } \\
\text { they have ever } \\
\text { used or not. }\end{array}$ & 0.000 & $\begin{array}{l}\text { Reject the } \\
\text { null hypothesis. }\end{array}$ \\
\hline
\end{tabular}

Specifically, Tab. 9 shows that the limited liability companies and joint stock companies are more interested in tax consulting services than private enterprise. This result reflects the fact in Vietnam that the private enterprises are mainly small-sized businesses. As a result, the number of business transactions is not too large, which leads to low intention. Another reason is the marketing strategies of the tax consulting company, which have not been focused on small and medium size enterprises. Based on these results, in addition to supporting policies on the type of joint-stock companies and limited liability companies, which are the major customers, the tax consulting companies should devote more attention to small-sized companies to create more diverse sources of customers.

Tab. 9: Crosstab table for relationship between type of company and intention.

\begin{tabular}{|c|c|c|c|c|c|}
\hline \multicolumn{7}{|c|}{ Type of company } \\
\hline \multirow{2}{*}{\multicolumn{2}{|c|}{}} & $\begin{array}{c}\text { Joint } \\
\text { stock }\end{array}$ & $\begin{array}{c}\text { Limited } \\
\text { liability }\end{array}$ & $\begin{array}{c}\text { Private } \\
\text { company }\end{array}$ & Total \\
\hline \multirow{2}{*}{ Intention } & 0 & 7 & 20 & 12 & 39 \\
\cline { 2 - 6 } & 1 & 7 & 53 & 9 & 69 \\
\hline Total & & 14 & 73 & 21 & 108 \\
\hline
\end{tabular}

Table 10 presents that the intention of using tax consulting services is high for companies that have used the services before and is low for the opposites. It can be inferred that tax consulting services really have many benefits which leads to high trusting intention of old customers. Another reason may be that advertising and promoting tax consulting service have not been interested in best way by tax consulting companies. Therefore, tax consulting companies should pay more attention to marketing strategies to improve intention of using tax consulting service of companies in Ho Chi Minh city.

Tab. 10: Crosstab table for relationship between "whether the company has ever used tax consulting service or not" and intention.

\begin{tabular}{|c|c|c|c|c|}
\hline \multicolumn{2}{|c|}{} & \multicolumn{2}{|c|}{ Has ever used } & Total \\
\cline { 3 - 5 } \multicolumn{2}{|c|}{} & 0 & 1 & \\
\hline \multirow{2}{*}{ Intensions } & 0 & 34 & 6 & 40 \\
\cline { 2 - 5 } & 1 & 14 & 58 & 72 \\
\hline Total & & 48 & 64 & 112 \\
\hline
\end{tabular}

\section{DISCUSSION}

Through Sec 3. it can be demonstrated that the intention of using tax consulting service depends positively on the "attitude toward the behavior" but depend negatively on "attracted by replacement", for companies in Ho Chi Minh city. Based on the obtained results, the following proposals are presented.

\subsection{Improve the Attitude Toward the Behavior}

Tax consulting companies need to focus on the convenience, progress and quality of consulting works. In addition to have specific strategies corresponding to each customer type, they should usually provide information and update on progress the works to help the customers can control the schedule when using services. Furthermore, tax consulting companies also need to expand the content of consulting services, enhance the consultation processes and simplify the administrative procedures for customers. Moreover, tax consulting companies need to develop a reasonable mechanism and focus on updating related legislation for decreasing errors in consulting process. In addition, companies 
should also provide managing information to help their clients have the appropriate planning in matters relating to taxation.

\subsection{Pay More Attention to Marketing Strategies}

When the convenience of tax consulting service is realized, the intention of using services can increase significantly. Hence, tax consulting companies need to support the branding programs to help customers realize the quality and usefulness of tax consulting services. In addition, activities such as designing the website, participating in professional forums (websites of tax association and tax department), participating in social activities, organizing conferences also need to be interested. Furthermore, tax consulting companies should also get feedback on the services they provide so that they can improve the business processes and capture the new demands of customers.

\section{CONCLUSIONS}

Through statistical technique such as Confirmatory Factor Analysis (CFA), Structural Equation Modeling (SEM) and Chi-square test, this article overcomes the limitations of previous study on the intention of using tax consulting services in Viet Nam. The results of this study have proven that the intention of using tax consulting services depend on two factors: attitude toward the behavior and replacement. In particular, attitude toward the behavior has a positive influence and replacement has a negative influence on the intention. Additionally, join stock companies and limited libiality companies are more interested in tax consulting services than private enterprise; the intention of using tax consulting services is higher for companies that have used the services than the opposites. From these results, this study proposes some discussions and recommendations to improve the intention of using tax consulting services of companies in $\mathrm{HCMC}$ and to minimize the risk of profuse occurs due to wrong implementation of tax provisions.

\section{Acknowledgment}

We wish to thank the editor and the anonymous reviewers for their careful reading of our manuscript and their many insightful comments and suggestions.

\section{References}

[1] ALEXANDER, R. M. The Effects of Source Credibility on Tax Professional Judgment in Consulting Engagements. Journal of the American Taxation Association. 2003, vol. 25 , iss. 1 , pp. 33-49.

[2] DHALIWAL, D. S., R. GAL-OR, V. NAIKER and D. SHARMA. The influence of the audit committee on auditor provided tax planning services. SSRN Electronic Journal. 2013,

[3] SOKOLOWSKA, E. Alternative Investments in Wealth Management: A Comprehensive Study of the Central and East European Market. 1st ed. New York: Springer, 2014.

[4] TRIEU, N. T., N. T. THAO and T. T. HA. Factors influencing the intention of using tax consulting services of firms in $\mathrm{Ho}$ Chi Minh city. In: 3rd International Conference on Finance and Economics. Ho Chi Minh: Tomas Bata University in Zlin, 2016, pp. 653-660.

[5] AJZEN, I. The theory of planned behavior. Organizational Behavior and Human Decision Processes. 1991, vol. 50, iss. 2, pp. $179-211$.

[6] DAVIS, F. D. Perceived Usefulness, Perceived Ease of Use, and User Acceptance of Information Technology. MIS Quarterly. 1989, vol. 13, no. 3, pp. 319-340.

[7] BAGOZZI, R. P., F. D. DAVIS and P. R. WARSHAW. Development and Test of a Theory of Technological Learning and Usage. Human Relations. 1992, vol. 45, iss. 7, pp. 659-686. 
[8] HEATH, Y. and R. GIFFORD. Extending the Theory of Planned Behavior: Predicting the Use of Public Transportation. Journal of Applied Social Psychology. 2002, vol. 32 , iss. 10, pp. 2154-2189.

[9] DE GROOT, J. and L. STEG. General Beliefs and the Theory of Planned Behavior: The Role of Environmental Concerns in the TPB. Journal of Applied Social Psychology. 2007, vol. 37 , iss. 8 , pp. 1817-1836.

[10] LONG, B., K. CHOOCHARUKUL and T. NAKATSUJI. Psychological Factors Influencing Behavioral Intention Toward Future Sky Train Usage in Phnom Penh, Cambodia. Transportation Research Record: Journal of the Transportation Research Board. 2011, vol. 2217 , iss. 1 , pp. 63-70.

[11] LI, L., J. XIONG, A. CHEN, S. ZHAO and Z. DONG. Key Strategies for Improving Public Transportation Based on Planned Behavior Theory: Case Study in Shanghai, China. Journal of Urban Planning and Development. 2015, vol. 141, iss. 2, pp. 40144019 .

[12] LEE, S.-H. and H. T. B. NGOC. Investigating the on-line shopping intentions of Vietnamese students: an extension of the theory of planned behaviour. World Transactions on Engineering and Technology Education. 2010, vol. 8, no. 4, pp. 471-476.

[13] FINCH, J. F. and S. G. WEST. The Investigation of Personality Structure: Statistical Models. Journal of Research in Personality. 1997, vol. 31, iss. 4 , pp. 439-485.

[14] PREEDY, V. R. and R. R. WATSON Handbook of Disease Burdens and Quality of Life Measures. 1st ed. New York: Springer, 2010.

[15] EFRON, B. The Jackknife, the Bootstrap and Other Resampling Plans. 1st ed. Philadelphia: SIAM, 1982.

[16] CHATTERJEE, S. Variance estimation in factor analysis: An application of the bootstrap. British Journal of Mathematical and Statistical Psychology. 1984, vol. 37, iss. 2, pp. 252-262.
[17] LAMBERT, Z. V, A. R. WILDT and R. M. DURAND. Approximating Confidence Intervals for Factor Loadings. Multivariate Behavioral Research. 1991, vol. 26, iss. 3, pp. 421-434.

[18] BOLLEN, K. A. and R. STINE. Direct and Indirect Effects: Classical and Bootstrap Estimates of Variability. Sociological Methodology. 1990, vol. 20, iss. 1, pp. 115140.

[19] BOLLEN, K. A. and R. STINE. Bootstrapping Goodness-of-Fit Measures in Structural Equation Models. Sociological Methods and Research. 1992, vol. 21, iss. 2, pp. 205-229.

[20] ICHIKAWA, M. and S. KONISHI. Application of the bootstrap methods in factor analysis. Psychometrika. 1995, vol. 60, iss. 1, pp. 77-93.

[21] NEVITT, J. and G. R. HANCOCK. Performance of Bootstrapping Approaches to Model Test Statistics and Parameter Standard Error Estimation in Structural Equation Modeling. Structural Equation Modeling: A Multidisciplinary Journal. 2001, vol. 8, iss. 3, pp. 353-377.

[22] KIM, Y. G. and G. LI. Customer Satisfaction with and Loyalty towards Online Travel Products: A Transaction Cost Economics Perspective. Tourism Economics. 2009 , vol. 15 , iss. 4 , pp. $825-846$.

[23] BOLLEN, K. A. and J. S. LONG. Testing Structural Equation Models. 1st ed. Newbury Park: SAGE Publications, 1993.

[24] BAUMGARTNER, H. and C. HOMBURG. Applications of structural equation modeling in marketing and consumer research: A review. International Journal of Research in Marketing. 1996, vol. 27, iss. 1, pp. 139161.

[25] MCCOACH, D. B. SEM Isn't Just the Schoolwide Enrichment Model Anymore: Structural Equation Modeling (SEM) in Gifted Education. Journal for the Education of the Gifted. 2003, vol. 13, iss. 2, pp. 36-61. 
[26] SUHR, D. D. Exploratory or confirmatory factor analysis?. SAS Institute Cary, 2006.

[27] SEGARS, A. H. and V. GROVER. ReExamining Perceived Ease of Use and Usefulness: A Confirmatory Factor Analysis. MIS Quarterly. 1993, vol. 17, no. 4, pp. $517-525$.

[28] CHIN, W. W. and P. A. TODD. On the Use, Usefulness, and Ease of Use of Structural Equation Modeling in MIS Research: A Note of Caution. MIS Quarterly. 1995, vol. 19 , no. 2, pp. 237-246.

[29] ANDERSON, J. C. and D. W. GERBING. Structural Equation Modeling in Practice: A Review and Recommended Two-Step Approach. Psychological Bulletin. 1988, vol. 103, no. 3, pp. 411-423.

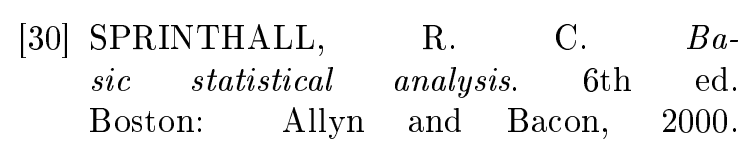

\section{About Authors}

Thao NGUYEN-TRANG was born in October, 1989. He received the Master degree in Probability and Statistics from Can Tho University in 2014. Currently, he is a Phd Student in University of Science, Ho Chi Minh City and is a researcher in Institute for Computational Science, Ton Duc Thang University, Vietnam. His primary research interests include statistics, economic statistics data mining.

Trieu NGUYEN-THI is a lecturer of Accounting at Faculty of Accounting, Ton Duc Thang University, Vietnam. She has spent almost decade in teaching accounting courses at tertiary level. Now, she is a Phd Student of University of Economics Ho Chi Minh City, her research with focuses on behavioral accounting, Corporate Social Responsibility (CSR), Social Enviroment report (SER), etc.

Ha CHE-NGOC works at Faculty of Mathematics and Statistics as a lecturer, Ton Duc Thang University. She graduated B.E. and M.E. degrees in Probability Theory and Mathematical Statistics in 2011 and 2014, respectively. Her research interests are Data mining, Classification, Clustering, Applied Statistics in Economics, Social.

"This is an Open Access article distributed under the terms of the Creative Commons Attribution License, which permits unrestricted use, distribution, and reproduction in any medium, provided the original work is properly cited (CC BY 4.0)." 